\title{
Boiler Blow down Heat Recovery
}

\author{
S.Arunkumar ${ }^{1}$, R.Prakash ${ }^{2}$, N.Jeeva ${ }^{3}$, M.Muthu ${ }^{4}$, B.Nivas ${ }^{5}$ \\ ${ }_{1,2,3}$ (Thermal Engineering, Bharathidasan College/ Anna University, India) \\ ${ }^{4}$ (Cad/Cam, Jayalakshimi College/ Anna University, India) \\ 5 (Engineering design,Priyardrashni College/ Anna University, India)
}

\begin{abstract}
Steam generators are widely used in industries for several purposes like power production, processing, heating etc. In industry steam generators are the major fuel consumers. In a normal steam generator about $4 \%$ of hot water is wasted as blow down. Due to this, a large amount of heat energy is wasted. This project aims to bring a heat recovery system to prevent heat losses, so that a large savings can be made. So in this a heat recovery system was designed to minimize the losses.
\end{abstract}

Keywords: steam generator

\section{Introduction}

Blow down is a process usually done in boilers to controls TDS (Total Dissolved Solids) of boilers water. This is done by removing the boilers water from the boiler drum at certain time intervals. The blow down energy system is indented to recover energy from blow down water. This is done by introducing a heat exchanger along with a flash chamber. Plate type heat exchanger is used in the system, which is used to absorb heat from hot water. This heat is supplied to the boiler feed water.

\section{BOILER REQUIREMENTS}

A boiler is the one which generates steam above atmospheric pressure. A boiler is a closed vessel which generates steam by transferring heat produced by burning of fuel to water. Steam generated is used for the following purpose.

POWER

Steam is used to drive prime movers like steam engine or steam turbine which in turn drive an electric generator to produce electricity.

PROCESSING Steam is used for industrial processing such as sizing, bleaching, etc.. REQUIRMENTS OF BOILER Safety: Boiler should be safe against high pressure steam and temperature under all working conditions. Accessibility: Various parts of boiler should be accessible for easy cleaning and inspection. Capacity: Boiler should be capable of meeting the required rate of steam production. Efficiency: Overall efficiency of the boiler should be as high as possible. Boiler's initial cost should be low. Boiler should be capable of quick starting and loading. Boiler should be simple in construction and cost of maintenance should be low.

\section{Coal Fired Boiler}

Coal fired boiler is a water tube boiler. It uses coal in powdered form as fuel. The boiler under study has a capacity of 42 tons. The designed working pressure is 21.5 b.Average load is about 28 tons. It uses fluidized bed combustion system

\section{Technical Details}

Type of system Atmospheric fluidized bed combustion system

Type of boiler Bi drum water tube boiler

Type of fuel Coal

Type of fuel feeding system - Pneumatic under bed feeding system

Design pressure at steam stop valve $21.5 \mathrm{kgcm} 2$

Design Flow rate $42 \mathrm{TPH}$

Furnace- 4 compartments, 16 fuel feed points

Manufacturing year 2009

Heating surface area 1510 sq.m

\section{Introduction To Blow Down}

In spite of all water treatment, dissolved solids will be present in shell type and water tube drum type boilers. In order to keep the limits and to remove any sludge, loose scales and corrosion products, a certain quantity of boilers is to be regularly drained. This process is called a BLOWDOWN. 
The quantity of water to be blow down will depend on the dissolved solids entering the boiler through the feed water and the maximum tolerable layers of the salts in the boiler water. Dissolved solids also get added up in the form of dosing.

In high pressure and medium pressure boilers, the quality of steam needs to be monitored closely, so as not to damage expensive and precise machines and processes such as heat-exchangers and turbines. The requirement is thus for clean, dry steam. On the other hand, the boiler too has to be run in the most efficient manner, keeping the condition of water at the optimum levels. This is achieved by blowing down the boiler where water from the boiler is purged and replaced by clean water. The control of blow down has thus been based on those parameters which are most likely to affect the area of application of steam and the boiler life.

Thus parameters that are most often monitored to ensure this quality of steam are TDS and conductivity, $\mathrm{pH}$, silicates and phosphates concentration. The boiler is blow down to reduce these levels and keep controlled to a point where the steam quality is not likely to be affected. A substantial amount of heat energy is lost in this process.

\section{Data Collected}

Working pressure $=21 \mathrm{Kg} / \mathrm{cm} 2$

Flash tank pressure $=0.5 \mathrm{Kg} / \mathrm{cm} 2$

Fuel used $=$ Coal

Boiler efficiency $=81 \%$

Steam generated $=650 \mathrm{TPD}$

Working days $=330$ days $/$ year

Required blow down $=3 \%$ of steam

Heat exchanger type : plate type

No: of plates : 20

Design pressure : $10 \mathrm{Kg} / \mathrm{cm} 2$

Area of heat exchange : $2.5 \mathrm{~m} 2$

\section{Blowdown Energy Recovery Calculation}

Amount of Blowdown,

$\mathrm{q}=20000 \mathrm{~kg} /$ day

Properties of Saturated Steam:

1. In Flash tank:

Flash tank pressure $=1.2 \mathrm{~kg} / \mathrm{cm} 2$

Sp. Enthalpy of water at $1.2 \mathrm{~kg} / \mathrm{cm} 2$,

$\mathrm{hf} 2=439.32 \mathrm{~kJ} / \mathrm{kg}$

Saturation Temperature at $1.2 \mathrm{~kg} / \mathrm{cm} 2=104.8 \mathrm{oC}$

Latent Heat at $1.2 \mathrm{~kg} / \mathrm{cm} 2$,

$\mathrm{hfg} 2=2244.2 \mathrm{~kJ} / \mathrm{kg}$

Sp. Enthalpy of steam at $1.2 \mathrm{~kg} / \mathrm{cm} 2$

, hg2 $=2683.5 \mathrm{~kJ} / \mathrm{kg}$

2. In Boiler:

Boiler Working Pressure $=21 \mathrm{~kg} / \mathrm{cm} 2$

Sp. Enthalpy of water at $21 \mathrm{~kg} / \mathrm{cm} 2$,

$\mathrm{hfl}=920.15 \mathrm{~kJ} / \mathrm{kg}$

Sp. Enthalpy of steam at $21 \mathrm{~kg} / \mathrm{cm} 2$

$\mathrm{hg} 1=2800 \mathrm{~kJ} / \mathrm{kg}$

3. In De-Aerator:

De-Aerator Pressure $=1.2 \mathrm{~kg} / \mathrm{cm} 2$

Sp. Enthalpy of water at $1.2 \mathrm{~kg} / \mathrm{cm} 2$,

$\mathrm{hf} 2=439.32 \mathrm{~kJ} / \mathrm{kg}$

Saturation Temperature at $1.2 \mathrm{~kg} / \mathrm{cm} 2=104.8 \mathrm{oC}$

Latent Heat at $1.2 \mathrm{~kg} / \mathrm{cm} 2$,

$\mathrm{hfg} 2=2244.2 \mathrm{~kJ} / \mathrm{kg}$

Sp. Enthalpy of steam at $1.2 \mathrm{~kg} / \mathrm{cm} 2, \mathrm{hg} 2=2683.5 \mathrm{~kJ} / \mathrm{kg}$

Heat Exchanger Data:

Overall Heat Transfer Coefficient, $U=1300 \mathrm{~W} / \mathrm{m} 2 \mathrm{~K}$

Area of Heat Exchange, $\mathrm{A}=2.5 \mathrm{~m} 2$

Hot Water inlet temperature, T1 $=$ Saturation Temp.in Flash Tank $=104.8 \mathrm{oC}$

Hot Water outlet temperature, $\mathrm{T} 2=75 \mathrm{oC}$ 
Cold Water inlet temperature, $\mathrm{t} 1=30 \mathrm{oC}$

Cold Water outlet temperature,

$\mathrm{t} 2=64.5 \mathrm{oC}$

Steam consumption of deaerator

$=20 \mathrm{TPD}($ at $21 \mathrm{~kg} / \mathrm{cm} 2)$

This steam input fully condenses to water at $1.2 \mathrm{~kg} / \mathrm{cm} 2$ releasing heat.

Thus, Energy input to deaerator

$=(2800-439.32) \times 20,000$

$=47.21 \times 106 \mathrm{~kJ} /$ day.

Heat Reovery from Flash steam:

Amount of Flash steam generated $=\mathrm{x} \mathrm{q}$

$=\mathrm{x} 20,000$

$=4283.75 \mathrm{~kg} /$ day.

This Flash steam is fed into deaerator where it completely condenses into water at $1.2 \mathrm{~kg} / \mathrm{cm} 2$.

Energy transferred from flash steam to deaerato

$\mathrm{r}=(2683.5-439.3) \times 4283.75$

$=9.614 \times 106 \mathrm{~kJ} /$ day.

Heat Reovery Through Heat Exchanger :

Logarithmic Mean Temp. Difference of Heat Exchanger $=$

LMTD , =

$=22.156 \mathrm{oC}$

Heat Exchanged, Q = UA x LMTD

$=1250 \times 2.5 \times 22.156$

$=69.237 \mathrm{~kW}=5.982 \times 106 \mathrm{~kJ} /$ day.

Thus, Total Heat Recovery via BHRS

\section{Conclusion}

$=(9.614 \times 106+5.982 \times 106) \mathrm{kJ} /$ day.

$=15.596 \times 106 \mathrm{~kJ} /$ day.

$=33.04 \%$ of Energy input to deaerator through steam at $21 \mathrm{~kg} / \mathrm{cm} 2$

$=0.3304 \times 20 \mathrm{TPD}$

$=6.61 \mathrm{TPD}$ Energy saving in the deaerator .

By using BHRS 6.61 total energy is saved in the process from the input steam.

\section{References}

[1] Heat transfer by J.P.HOLMAN mg-graw hill book company

[2] Thermodynamics by S.K MONDAL

[3] HEAT TRANSFER by S.K.MONDAL

[4] Heat pump and boilers by R.K 